\title{
MEMBANGUN DESA RELIGIUS DAN BERSIH DARI SAMPAH
}

\author{
Gunawan Ikhtiono $^{1}$, Reza Kusuma Ningrat, Mechka Dinda Ramadhanty ${ }^{2}$ \\ gunawan@fai.uika-bogor.ac.id \\ Dosen Fakultas Agama Islam¹, Mahasiswa KKN Kelompok 57 Tahun $2018^{2}$
}

\begin{abstract}
ABSTRAK
Religius yaitu suatu sikap dan perilaku yang taat/patuh dalam menjalankan ajaran agama yang dipeluknya, bersikap toleran terhadap pelaksaan ibadah agama lain, serta selalu menjalin kerukunan hidup antara pemeluk agama lain. ideologi religius itu menjelaskan dan melakukan perubahan dalam kehidupan sosial dan politik, akan tetapi masalah sosial di masyarakat masih seringkali bermunculan. Bersih dari sampah bebas mengacu pada pengelolaan sampah dan pendekatan perencanaan yang menekankan pencegahan sampah sebagai lawan dari pendekatan pengelolaan. Upaya kesehatan adalah setiap kegiatan untuk memelihara, dan meningkatkan kesehatan yang dilakukan oleh pemerintah, dan atau masyarakat. Pemberdayaan masyarakat merupakan sebuah konsep pembangunan ekonomi yang merangkum nilai-nilai sosial. konsep ini mencerminkan paradigma baru pembangunan, yakni yang bersifat "people-centered, participatory, empowering, and sustainable
\end{abstract}

Kata Kunci : Religius, Bebas Sampah, Pemberdaya

\section{PENDAHULUAN}

Desa Leuwiliang Kecamatan Leuwiliang mempunyai luas wilayah 297 Ha. Berdasarkan Kondisinya, lahan yang ada terbagi dalam dua ekosistem, yaitu ekosistem lahan sawah dan kolam, serta ekosistem lahan darat/kering. Luas lahan sawah sejumlah 76 ha dan luas kering dan permukiman sejumlah 172,6 ha. Pemanfaatan sumber daya alam di Desa belum dimanfaatkan baik sumber daya pertanian pangan perikanan peternakan belum dimanfaatkan secara optimal dan berkesinambungan.
Desa Leuwiliang Kecamatan Leuwiliang dengan Desa Leuwiliang terletak di

sebelah utara dengan jarak tempuh $0,5 \mathrm{~km}$ ke kantor Kecamatan Leuwiliang dan mempunyai unsur pembantu Pemerintah terbawah, terdiri dari 5 (lima) Dusun (kadus), 14 (empat belas) Rukun Warga (RW), dan 48 (empat puluh delapan) Rukun Tetangga (RT).

Jumlah Penduduk Berdasarkan

Kewarganegaraan:

\begin{tabular}{|l|l|l|}
\hline Laki-laki & Perempuan & Jumlah \\
\hline 8.674 & 8.255 & 16.929 \\
\hline
\end{tabular}




\section{METODE PELAKSANAAN}

\section{Tahap Pelaksanaan}

Tahapan pelaksanaan untuk kegiatan ini sebagaimana terlihat pada bagan sebagai berikut:

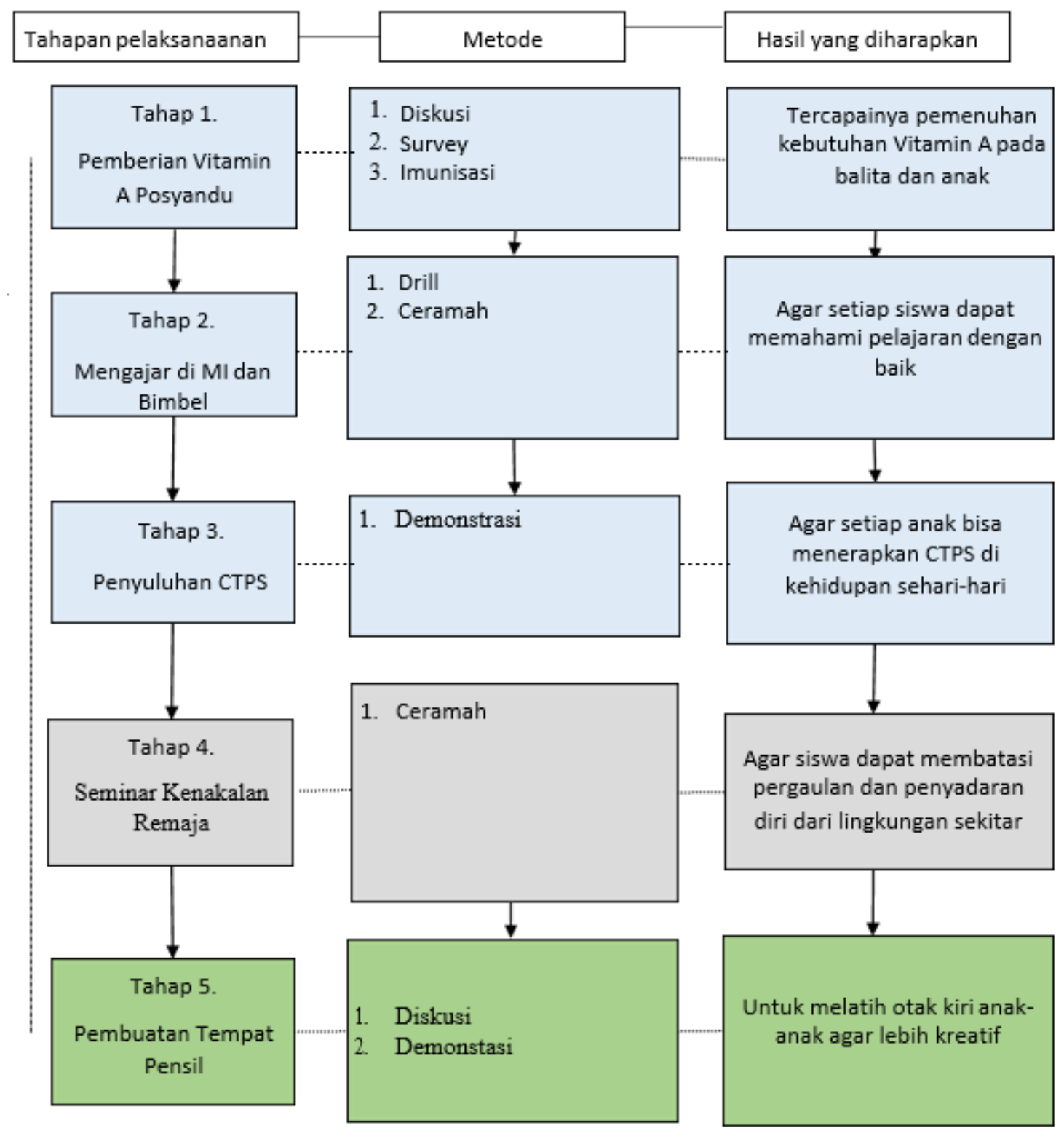




\begin{tabular}{|c|c|c|c|c|c|c|}
\hline \multirow{2}{*}{ No } & \multirow{2}{*}{ Kegiatan } & \multicolumn{5}{|c|}{ Minggu } \\
\hline & & 1 & 2 & 3 & 4 & 5 \\
\hline 1. & Penyusunan rencana kegiatan & & & & & \\
\hline 2. & Sosialisasi rencana kegiatan & & & & & \\
\hline 3. & kegiatan belajar mengajar, bimbel & & & & & \\
\hline 4. & Rapat pembangunan desa & & & & & \\
\hline 5. & Pemberian vitamin $\mathrm{A}$ & & & & & \\
\hline 6. & Pelaksanaan hut RI & & & & & \\
\hline 7. & Pemotongan kurban idul adha & & & & & \\
\hline 8. & Jumsih atau kerja bakti masjid & & & & & \\
\hline 9. & Mengajar di tpq & & & & & \\
\hline 10. & Penyuluhan cuci tangan pakai sabun (ctps) & & & & & \\
\hline 11. & Seminar "Kenakalan Remaja" & & & & & \\
\hline 12. & Mengecat dan memodifikasi tong sampah & & & & & \\
\hline 13. & Cek kesehatan & & & & & \\
\hline 14. & Pengajian pemuda, ibu-ibu, bapak- bapak & & & & & \\
\hline 15. & Pembuatan tempat pensil & & & & & \\
\hline
\end{tabular}

\section{Metode Pendekatan}

Pendekatan sosial kepada masyarakat dilakukan melalui media sebagai berikut :

1. Melalui pertemuan-pertemuan rutin warga ditingkat RT/RW/Dusun/Desa.

2. Melalui pengajaran TPQ.

3. Melalui pengajaran di MI.

4. Melalui kegiatan PAUD dan TK.

5. Melalui kegiatan karang taruna.

6. Melalui kegiatan pengajian ibu-ibu.

7. Melalui kegiatan ibu-ibu PKK.

\section{Partisipasi Masyarakat dalam Pelaksanaan Program}

Partisipasi masyarakat yang dapat dilakukan dalam kegiatan ini adalah sebagai berikut:

1. Mempersiapkan masyarakat yang bersedia mengikuti pembinaan tentang pentingnya kerukunan hidup antara pemeluk agama lain.

2. Mempersiapkan tempat untuk pembinaan dan pelatihan.

3. Pelaksana kegiatan seminar di desa, terutama tentang membangun desa religius dan bersih dari sampah.

\section{Langkah Evaluasi}

Evaluasi yang akan dilakukan terdiri dari:

1. Evaluasi proses, yang terkait dengan perencanaan, pelaksanaan dan monitoring kegiatan. Evaluasi proses akan dilakukan setiap pekan bersama dengan masyarakat.

2. Evaluasi hasil, yang akan dilaksanakan setelah kegiatan dilaksanakan. Evaluasi hasil: 
ditujukan untuk menguji pemahaman masyarakat sekitar tentang sampah yang

3. Evaluasi dampak, yang akan dilakukan 6 (enam) bulan setelah pelaksanaan pembinaan. Evaluasi dampak diarahkan untuk melihat efektivitas model pembinaan dan keberlangsungan industri rumah tangga (Gall dan Borg, 2003).

\section{HASIL PROGRAM}
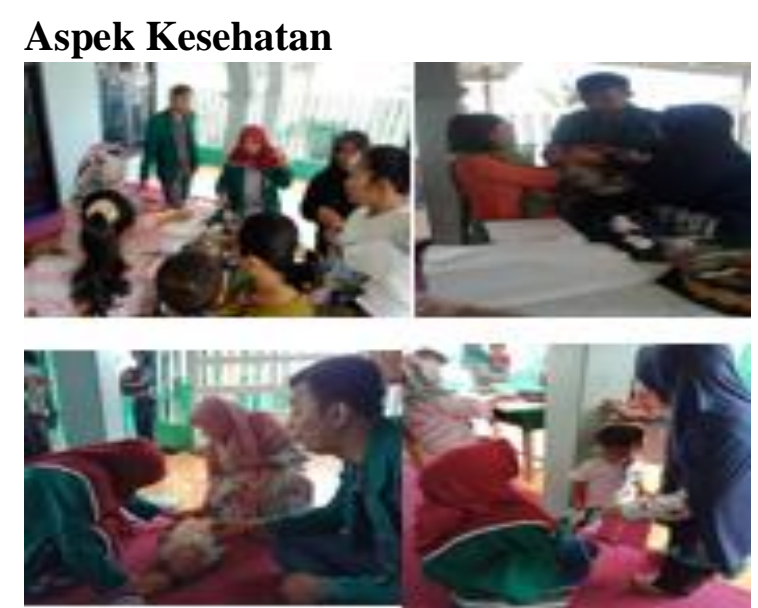

Memberikan Vit.A dan Pengukuran BB
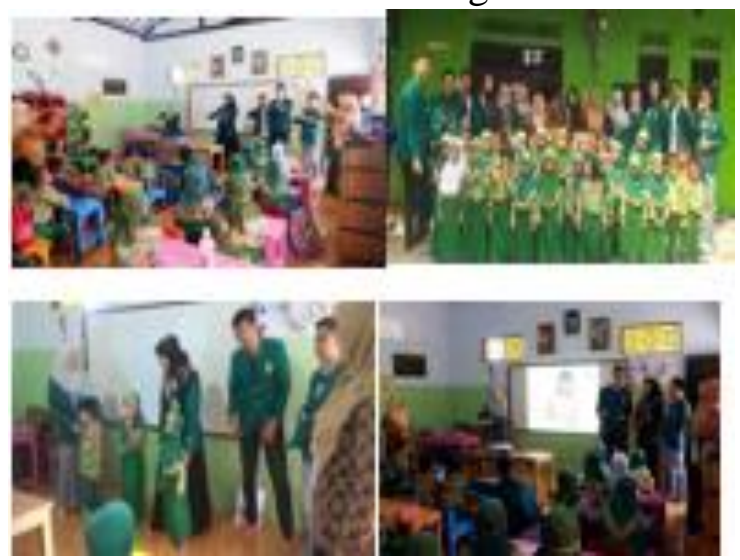

Penyuluhan CTPS ( Cuci Tangan Pake Sabun)

Senam Sehat
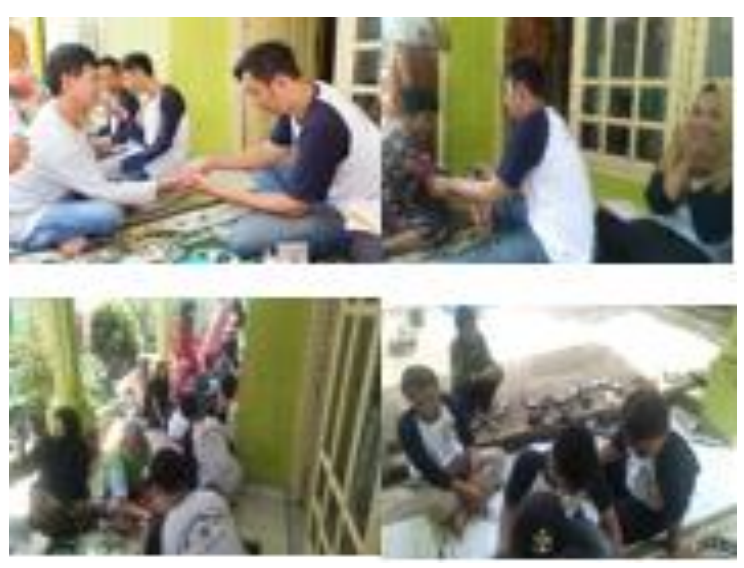

Cek Kesehatan

\section{Aspek Pendidikan}
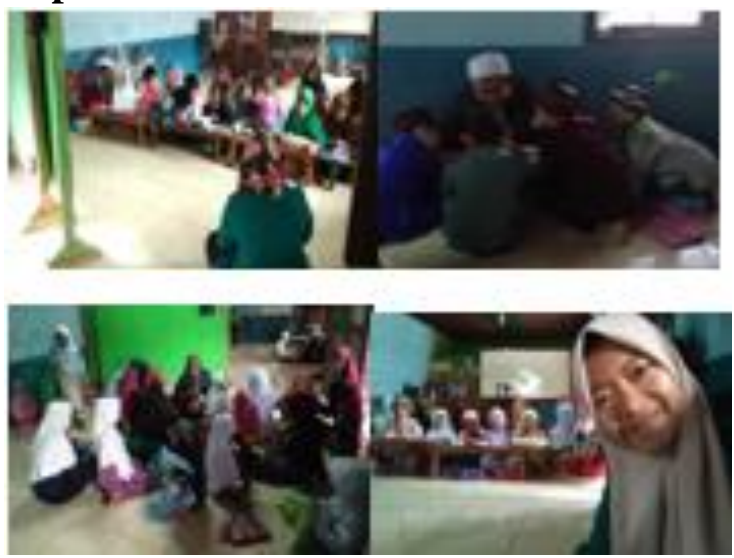

Bimbingan Belajar anak
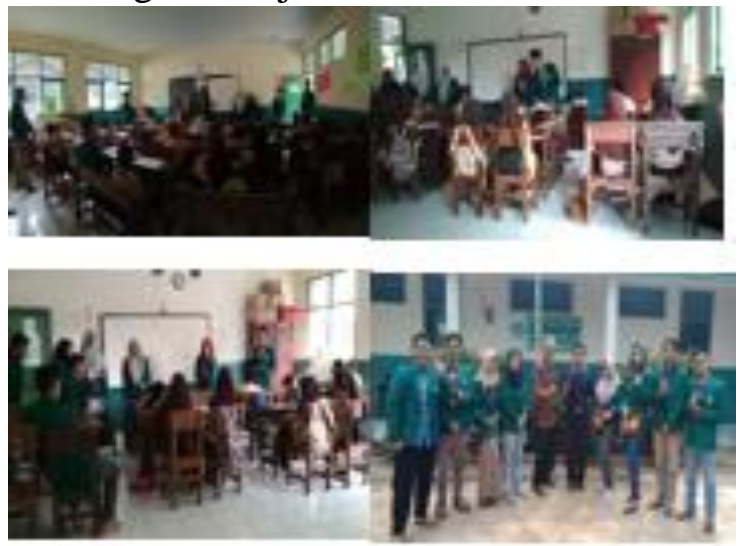

Mengajar MI 

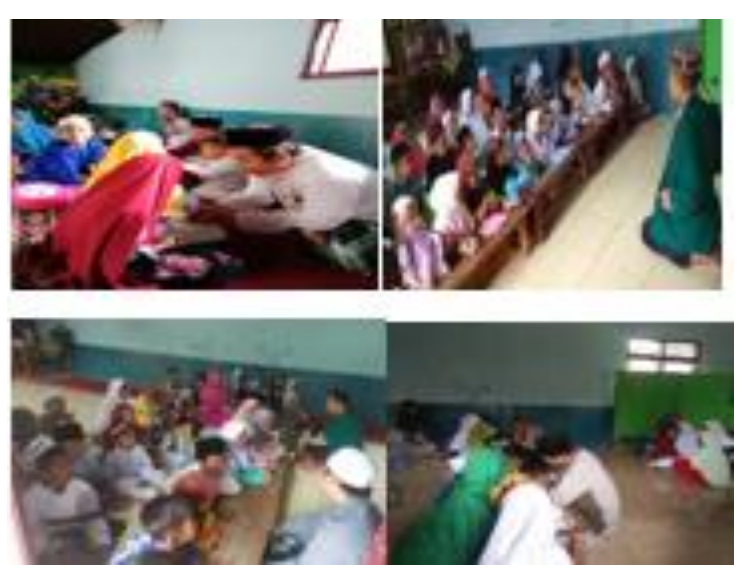

TPA ( Taman Pendidikan Al-Qur'an)
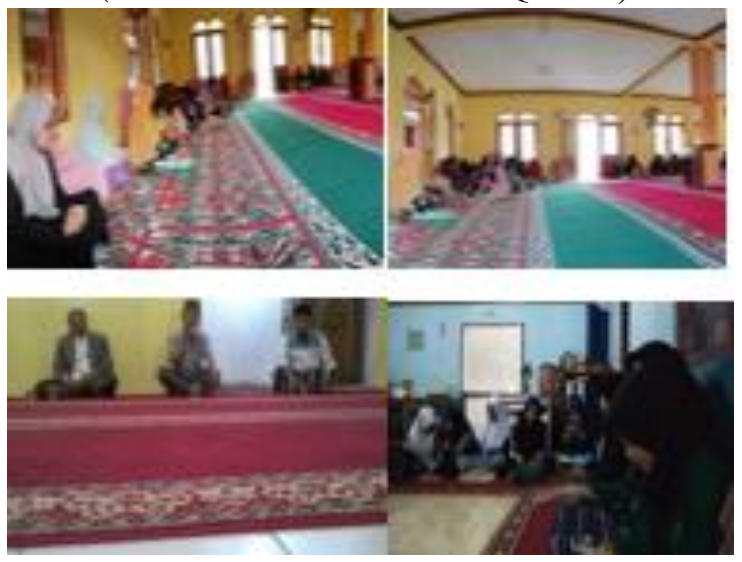

Pengajian

\section{Aspek Ekonomi}

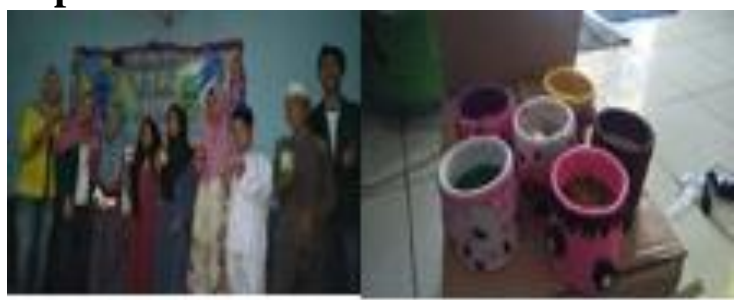

Daur Ulang Kaleng

\section{Aspek Lingkungan}
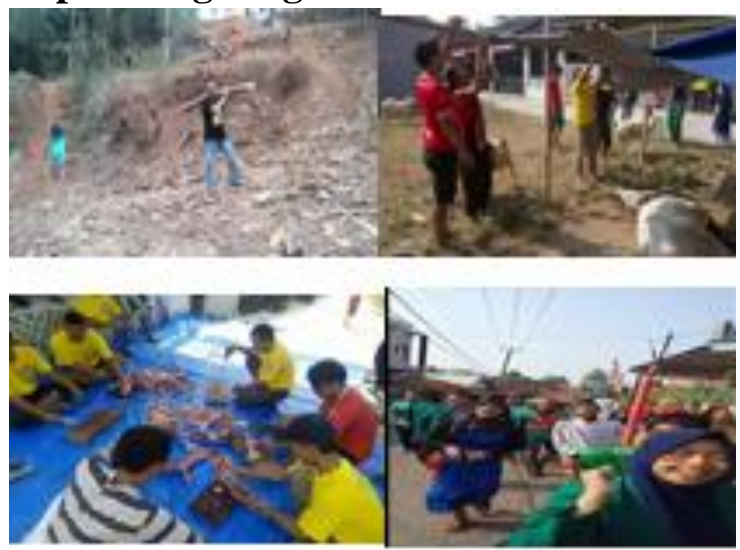

Gotong-royong
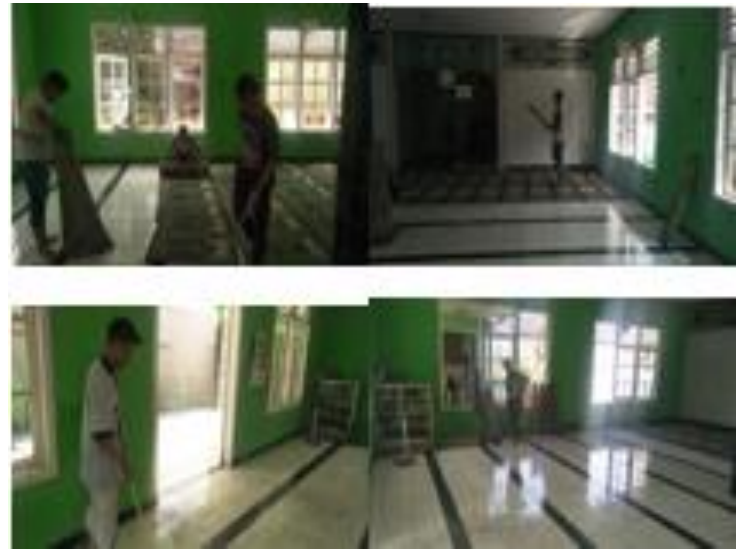

Jumsih atau Kerja Bakti Masjid

\section{Aspek Umum}

Seminar "Kenakalan Remaja"
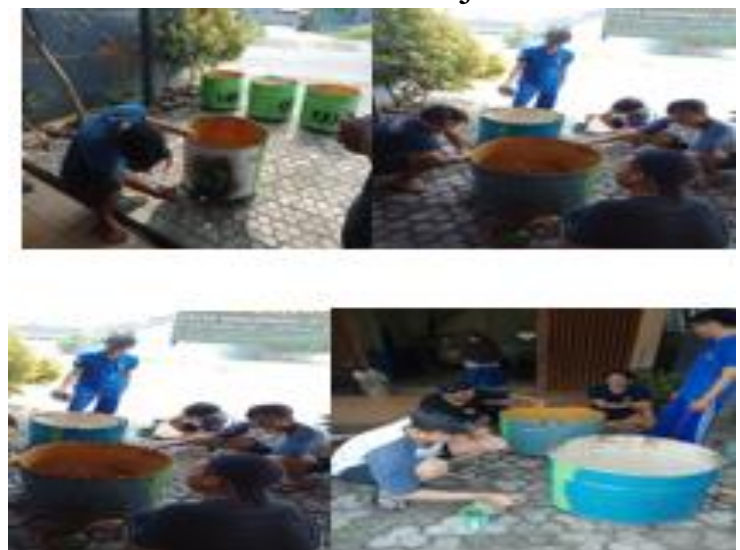

Menyebarkan tong sampah

\section{KESIMPULAN}

Berdasarkan hasil kegiatan, pengamatan, maupun pelaksanaan program kerja KKN yang telah direncanakan, disusun dan dilaksanakan. Maka kelompok 57 KKN UNIVERSITAS IBN KHALDUN BOGOR 2018 di Desa Leuwiliang Kecamatan Leuwiliang mengambil beberapa kesimpulan yaitu :

1. Keberhasilan KKN tidak lepas dari kerja sama antara mahasiswa dengan perangkat desa,masyarakat,serta semua pihak yang membantu dan mendukung terlaksananya kegiatan KKN tanpa adanya kerja sama yang baik, program kerja KKN tidak akan berjalan dengan lancar. 
2. Dengan adanya mahasiswa KKN para masyarakat mencoba mencontoh cara berfikir mahasiswa untuk befikir modern.

3. Dengan adanya mahasiswa KKN masyarakat terbantu dengan bertambahnya informasi dan ilmu pengetahuan yang mereka peroleh dari mahasiswa KKN.

4. Dengan adanya mahasiswa KKN karang taruna di Desa Leuwiliang lebih aktif.

5. Teori yang didapat di bangku kuliah tidak semua sesuai dengan situasi dan kondisi lapangan.

6. Kurangnya kepedulian masyarakat desa terhadap lingkungan sekitar

7. Potensi desa di Desa Leuwiliang telah dikelola cukup baik oleh masyarakat, sehingga tercapai hasil yang cukup memuaskan, diantaranya :

a. Kerjasama yang baik antara masyarakat, perangkat desa serta instansi terkait guna memperlancar pembangunan desa.

b. Perbaikan dan pemeliharaan jalan sehingga dapat membuka wilayah desa yang terisolisir dan dapat memperlancar transportasi.

c. Keterbukaan aparat desa terhadap masyarakat, mampu menjalin hubungan komunikasi yang baik.

d. Pemberdayaan swadaya masyarakat untuk menunjang pembangunan desa.

Dengan demikian, hasil kesimpulan di atas menunjukan bahwa secara garis besar program KKN kelompok 57 dapat dikatakan sukses dan lancar meskipun ada beberapa kendala baik dari pihak mahasiswa maupun pihak masyarakat di Desa Leuwiliang namun itu tidak berpengaruh terhadap program yang telah direncanakan.

\section{REFEREENSI}

2017, Pelaporan Pedoman PPM Universitas Ibn Khaldun Bogor.

https://kkn.unnes.ac.id/lapkkn/11402_3324

122015_Desa\%20Tratemulyo_2014

1223_1

10650.pdf\#page $=21 \&$ zoom $=80,-$ 335,542

http://eprints.uny.ac.id/28442/1/laporan\%2 0Kelompok\%20KKN\%202041.pdf

Fahmi eroby, 2008, Pendidikan berbasis masyarakat. Yogyakarta 